Aquaculture

April 2006; 254(1-4) : 544-553

http://dx.doi.org/10.1016/j.aquaculture.2005.11.017

(c) 2005 Elsevier B.V. All rights reserved
Archimer, archive institutionnelle de l'Ifremer http://www.ifremer.fr/docelecl

\title{
Nutritional value of six Pavlovophyceae for Crassostrea gigas and Pecten maximus larvae
}

\author{
E. Ponis ${ }^{a, b}$, I. Probert ${ }^{c}$, B. Véron ${ }^{b},{ }^{c}$, J.R. Le $\operatorname{Coz}^{d}, M^{\text {M. Mathieu }}{ }^{b}$ and R. Robert ${ }^{a *}$ \\ aUMR100 IFREMER - Physiologie et Ecophysiologie des Mollusques Marins, Laboratoire de Physiologie des \\ Invertébrés Marins, Station Expérimentale d'Argenton, Presqu'île du Vivier, 29840 Landunvez, France \\ bUMR100 IFREMER - Physiologie et Ecophysiologie des Mollusques Marins, Laboratoire de Biologie et \\ Biotechnologies Marins, Université de Caen Basse Normandie, 14032 Caen Cedex, France \\ ${ }^{\mathrm{c}}$ Algobank-Caen, ISBIO, Université de Caen Basse-Normandie, 14032 Caen Cedex, France \\ dUMR100 IFREMER - Physiologie et Ecophysiologie des Mollusques Marins, Laboratoire de Physiologie des \\ Invertébrés Marins, 29200 Brest, France \\ *: Corresponding author : Tel.: +33 2988951 05; fax: +33 2988957 77. rrobert@ifremer.fr
}

\begin{abstract}
Four unidentified new strains of Pavlovophyceae [Pavlova sp. AC 250 (Pfl), Pavlova sp. AC 248 (Psh), Pavlova sp. AC 251 (Pth), Pavlova sp. AC 538 (Psm)] and two known species [Pavlova pinguis (Ppi), Rebecca salina (ex Pavlova salina, Rsa)] were characterized (productivity, size, dry weight, ash, gross composition, fatty acids, sterols) and their nutritional value in bispecific diets were evaluated both on Crassostrea gigas and Pecten maximus larvae. All microalgae exhibited poor food value for C. gigas larvae. P. pinguis and R. salina did not sustain any growth, like the control starved larvae. No exo-toxicity of P. pinguis and R. salina was detected. These two species were weakly ingested by C. gigas larvae, while the four other pavlovophytes were effectively grazed. When used as food for P. maximus larvae, P. pinguis and Psh led to poor development. In contrast, a diet with Pfl resulted in significantly better growth than the control.
\end{abstract}

Keywords: Microalgae; Nutritional value; Larval nutrition; Biochemical composition 


\section{Introduction}

In mollusc hatcheries the main criteria for the suitability of microalgal strains are that they should be readily and easily cultured, rapidly ingested and digested, and they must exhibit a high nutritional value, particularly with respect to the highly unsaturated fatty acids (Robert et al., 2004). Less than ten microalgal strains are routinely used in mollusc hatcheries, and this fact represents a constraint for the full development of this activity (Coutteau and Sorgeloos, 1992; Robert et al., 2004). Accordingly, the identification of new microalgal species of good food value for larvae constitutes one of the priorities of research related to this field (Brown et al., 1998; Renaud et al., 1999; Knuckey et al., 2002; Renaud et al., 2002). The microalgae routinely produced as feed in commercial mollusc hatcheries includes several diatoms (Skeletonema costatum, Thalassiosira pseudonana clone $3 \mathrm{H}$, Chaetoceros gracilis, C. calcitrans, C. calcitrans forma pumilum, C. muelleri) and only two flagellates (Isochrysis aff. galbana clone T-Iso, Pavlova lutheri), while Tetraselmis sp. is somewhat used mainly for spat.

The haptophyte class Pavlovophyceae is composed by flagellates of appropriate size (3-5 $\mu \mathrm{m})$ for ingestion by mollusc larvae. These species are also generally rich in polyunsaturated fatty acids (PUFA), which are essentials for molluscs (Volkman et al., 1991; Kanazawa et al., 1979). Different pavlovophytes have been used as feeds for molluscs (Pavlova lutheri, P. pinguis, Rebecca salina) with contrasting outcomes, depending on the mollusc species and on the stage concerned: $P$. lutheri was found to be effective for feeding Pecten maximus and $P$. fumatus larvae, while it was of poor food value for C. gigas larvae (Heasman et al., 2000; Ponis et al., 2003a,b; Laing, 2004); P. pinguis was successfully used as food for C. gigas spat (Brown et al., 1998; McCausland et al., 1999); R. salina has been used to feed different types of oysters (C. gigas spat, McCausland et al., 1999; Pinctada margaritifera larvae, Doroudi et al., 1999, 2003; Southgate et al., 1998; Saccostrea echinata larvae, Southgate and Lee, 1998). In this study, six pavlovophytes were characterized in terms of cell density, productivity, dry weight, ash content, gross composition, and fatty acid and sterol contents in order to assess their potential food value for larval nutrition. These species were then tested as food for Pacific oyster (C. gigas) and king scallop (P. maximus) larvae.

\section{Materials and methods}

\subsection{Microalgal culture}

The six strains were selected from the Algobank-Caen microalgal culture collection of the University of Caen Basse-Normandie. All strains were clonal, a single cell having been isolated from seawater samples (from diverse locations) by micropipette (Table 1). They will be quoted in the text as Pfl = Pavlova sp. AC 250, Psh = Pavlova sp. AC248, Pth = Pavlova sp. AC 87, Psm = Pavlova sp. AC 538, Ppi $=$ Pavlova pinguis and Rsa $=$ Rebecca salina $($ ex Pavlova salina). Microalgae were grown in 2-l glass carboys at $22-23{ }^{\circ} \mathrm{C}$ under continuous illumination at an intensity of $180-220 \mu \mathrm{mol}$ photons $\mathrm{m}^{-2} \mathrm{~s}^{-1}$, provided by cool white fluorescent tubes. Seawater (salinity 34-35\%) was $1 \mu \mathrm{m}$ filtered, enriched with sterilized Conway medium (Walne, 1966) and then autoclaved. A 3\% $\mathrm{CO}_{2}$-air mixture was supplied in order to support growth and to maintain the $\mathrm{pH}$ within a range of 7.5-8.1. For culture of the diatom Chaetoceros calcitrans forma pumilum, sodium metasilicate $\left(40 \mathrm{mg} \mathrm{l}^{-1}\right)$ was added as a silica source and salinity was reduced to $25 \%$ by addition of distilled water. 
Table 1. Size and growth characteristics of the six pavlovophytes used in the experimental feeding trials (mean \pm S.D.; size $n \geq 15000$; concentration and growth rate $n=2$ ).

\begin{tabular}{|c|c|c|c|c|c|}
\hline Strains & Code & Origin & \begin{tabular}{|l}
$\begin{array}{l}\text { Diameter } \\
(\mu \mathrm{m})\end{array}$ \\
\end{tabular} & $\begin{array}{l}\text { Concentration } \\
\left(\times 10^{6} \mathrm{ml}^{-1}\right)\end{array}$ & 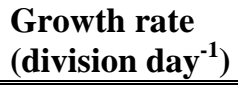 \\
\hline Pavlova sp. (Pfl) & (AC 250) & Mediterranean & $5.3 \pm 1.5$ & $9.7 \pm 0.7$ & $0.7 \pm 0.1$ \\
\hline Pavlova sp. (Psh) & (AC248) & Mediterranean & $4.5 \pm 0.6$ & $12.7 \pm 0.5$ & $0.8 \pm 0.1$ \\
\hline Pavlova sp. (Psm) & (AC 538) & North Atlantic & $4.7 \pm 0.9$ & $13.4 \pm 0.8$ & $0.8 \pm 0.1$ \\
\hline Pavlova pinguis (Ppi) & (AC19) & Mediterranean & $4.5 \pm 1.1$ & $11.0 \pm 0.3$ & $0.7 \pm 0.1$ \\
\hline Pavlova sp. (Pth) & (AC 251) & Indian Ocean & $3.8 \pm 0.8$ & $20.9 \pm 1.0$ & $0.9 \pm 0.1$ \\
\hline Rebecca salina (Rsa) & (AC87) & North Atlantic & $4.4 \pm 1.0$ & $12.6 \pm 2.1$ & $0.8 \pm 0.1$ \\
\hline
\end{tabular}

\subsection{Feeding trials with C. gigas and P. maximus larvae}

Pacific oyster larvae were obtained from previously conditioned broodstock. Conditioning methods and fecundation procedures were similar as those described by Robert et al. (2001). Embryonic development was carried out at $24{ }^{\circ} \mathrm{C}$ in $150-\mathrm{l}$ tanks containing gently aerated seawater ( $1 \mu \mathrm{m}$ filtered, salinity 34-35\%) at a density of 50 larvae $\mathrm{ml}^{-1}$. Feeding trials with $C$. gigas were carried out with larvae with an initial age of 2 days. Larvae were kept in 2-l glass beakers at a density of $5 \mathrm{ml}^{-1}$ and maintained at $24^{\circ} \mathrm{C}$. During feeding trials, each lasting 14 days, pavlovophytes were tested in mixed diets, each running in triplicate, in association with the diatom $C$. calcitrans forma pumilum. Indeed, single diets does not allow sufficient $C$. gigas larval growth and most often high mortality occurs in such monospecific feeding experiment, leading to bias resulting in data difficulty interpretation. C. calcitrans forma pumilum is a very high nutritional diatom for C. gigas (Robert et al., 2005) and, when used in mixtures, cautions must be taken to do not mask the effect of the other microalgae. To point out the food value of the different pavlophytes without diatom overlap the bispecific diets were accordingly composed of $80 \%$ flagellate and $20 \%$ diatom; based on cellular volume, all microalgae were similar when used. This method was preferred to that of dry weight equivalent because rapid checking could be performed easily on all phytoplanctonic cultures using a Coulter counter linked to a channelyser. C. gigas larvae were fed with microalgae harvested in exponential phase. Different control groups were included in each trial: starved larvae as a negative control, and a group fed a standard diet (C. calcitrans f. pumilum + Isochrysis aff. galbana clone T-Iso) as a positive control (Robert et al., 2005). In addition, the diatom was included as the sole component in two other control groups, one fed $20 \%$ (corresponding to the diatom quantity included in bispecific diets) and one at $100 \%$ ration. In such small volume it is not recommended to aerate the culture while an excess of microalgae has negative effect on larval development (Helm and Bourne, 2004). In 2-l beakers no air was accordingly supplied while food was delivered every other day, at each seawater renewal; the standard daily food ration gave a total cell concentration of 50 cells $\mu l^{-1}$ for the first week and 100 cells $\mu^{-1}$ for the second week which is sufficient to cover the demand at a density of 5 larvae. $\mathrm{ml}^{-1}$.

An additional feeding trial was set up in order to verify the potential toxicity of $P$. pinguis and $R$. salina exudates for $C$. gigas larvae. Cultures of both strains were harvested during the exponential phase of growth and then centrifuged (3200 g, $5 \mathrm{~min}$ ); thereafter, $20 \mathrm{ml}$ of the 
supernatant were added to larvae together with a monospecific diet of C. calcitrans $\mathrm{f}$. pumilum, while the pellets were resuspended in 1- $\mu \mathrm{m}$ filtered seawater and used to feed another control group.

Larvae were sampled at the start, after one week and at the end of the feeding trials. At each sampling time at least 200 larvae were collected for each replicate in order to assess mortality by counting the translucent larval shells, and to measure the major length, defined as the antero-posterior axis parallel to the hinge, by means of image analysis. For this purpose a digital camera was connected to a microscope and acquired images were analysed with the IMAQ Vision Builder software (National Instruments).

Lastly, to check the effective ingestion of the different pavlophytes, a grazing test was also performed on $C$. gigas larvae. This sole trial was set up to verify if the poor food value recorded in the previous trials could be related to microalgae uptake. A batch of larvae were grown in 150-l tanks and fed with a multispecific diet composed of T-Iso and C. calcitrans $\mathrm{f}$. pumilum. After a day of starvation, larvae aged 16 days were transferred, at a density of $5 \mathrm{ml}^{-}$ ${ }^{1}$, into 30-l cylindro-conic tanks, each containing a pavlovophyte at an initial density of 100 cell $\mu^{-1}$. In such volume constant air-bubbling was supplied to avoid sedimentation of microalgal cells. A sample from each tank was collected hourly, sieved $(20 \mu \mathrm{m})$ to remove larvae, and total particles counted with a Counter coulter (ZN) during an 8h period.

$P$. maximus larvae were obtained from a commercial hatchery (Tinduff, France) and were 4 days old at the beginning of the feeding trials. Rearing and analysis methods were similar as those described for $C$. gigas larvae, except for a lower temperature $\left(18^{\circ} \mathrm{C}\right)$ and the addition each 2 days of thiamphenicol $\left(7 \mathrm{mg} \mathrm{l}^{-1}\right)$ to limit bacterial contamination. Moreover, the diets based solely on the diatom were excluded from the trial.

\subsection{Analytical procedures}

Phytotechnical and biochemical analyses were performed in duplicate with biomass harvested after six days of culture at which point cultures were in exponential or late exponential phase of growth. Microalgae biochemical composition was examined concurrently with larval feeding experiments which means that for each species three samples were performed during larval development. Growth was estimated daily using a Malassez haemocytometer; growth rate was calculated as: $\mu=\left[\left(\operatorname{lnN}_{1}-\ln N_{0}\right) /\left(\mathrm{t}_{1}-\mathrm{t}_{0}\right)\right] / \ln 2$, where $\mathrm{N}_{1}=$ measurement at time $1\left(\mathrm{t}_{1}\right), \mathrm{N}_{0}$ $=$ measurement at time $0\left(\mathrm{t}_{0}\right)$. Cellular size, expressed in diameter equivalent, was determined using a Channelyser C256.

Dry weight measurements were obtained by centrifuging (3200g, $10 \mathrm{~min}$ ) $50 \mathrm{ml}$ of culture; pellets were then rinsed with $20 \mathrm{ml}$ of ammonium formate $0.5 \mathrm{M}$, centrifuged again and then transferred into pre-weighed tin capsules. Dry weight and ash content were measured after heating at $80^{\circ} \mathrm{C}$ (overnight) and $450{ }^{\circ} \mathrm{C}(4 \mathrm{~h})$, respectively. For gross composition, $50 \mathrm{ml}$ of culture were harvested by centrifugation (3000 r.p.m., $10 \mathrm{~min}$ ); pellets were stored at $-20^{\circ} \mathrm{C}$ for a period of up to six months prior to analysis. Proteins, lipids and carbohydrates were analysed using the methods described by Lowry et al., (1951), Dubois et al. (1956) and Bligh and Dyer, (1959), respectively. For fatty acid and sterol analyses, samples of 10-50 ml of culture, according to cellular concentration, were filtered through 47-mm precombusted (450 ${ }^{\circ} \mathrm{C}$ for $8 \mathrm{~h}$ ) Whatman $\mathrm{GF} / \mathrm{F}$ glass-fibre filters and stored at $-20{ }^{\circ} \mathrm{C}$ in chloroform/methanol $(2 / 1)$ for a period of up to six months prior to analysis. For fatty acid analysis, neutral and polar lipids were separated in a silica gel microcolumn (30 mm x 5 mm; Kieselgel Merck, 70$230 \mu \mathrm{m}$ mesh), previously heated to $450{ }^{\circ} \mathrm{C}$ and deactivated with $5 \%$ water, as described by Soudant et al. (1995). Fatty acid analyses were performed according to the method described by Marty et al. (1992), using a Hewlett-Packard HP6890 gas-chromatograph, equipped with a J\&W 65 DB Wax column (30 m x $0.25 \mathrm{~mm}$; $0.25 \mu \mathrm{m}$ film thickness), using hydrogen as the 
carrier gas and 23:0 as the internal standard. Sterols of the neutral lipid fraction were analysed according to Soudant et al. (2000), using a Chrompack CP 9002 gas chromatograph equipped with a Restek Rt X 65 fused silica capillary column $(15 \mathrm{~m}$ x $0.25 \mathrm{~mm}, 0.25 \mu \mathrm{m}$ film thickness), using hydrogen as the carrier gas and cholestane as the internal standard.

Biochemical analysis results (gross, fatty acids and sterol compositions) were expressed in relative terms (percentage of organic matter or percentage of total fatty acids or total sterols) allowing comparisons independently of microalgae cells weight which increased from exponential to stationary phases. Total fatty acids and total sterols weights were also reported to allow quantitative terms calculations (weight of each component per cell $=$ total weight* relative composition).

\subsection{Statistics}

Significant differences between feeding experimental conditions were detected by means of ANOVA and Scheffe tests $(\mathrm{P}<0.05)$ and data expressed in percentage previously transformed (arcsine square root $\mathrm{x}_{\mathrm{i}} 100^{-1}$ ) before statistical treatments.

\section{Results}

\subsection{Size, growth, biochemical composition of the microalgae}

Cellular size of the pavlovophyte strains used varied between 3.8 (Pth) and $5.3 \mu \mathrm{m}$ (Pfl) in equivalent diameter, while dry weight ranged from 14.8 (Pfl) to 28.8 pg cell $^{-1}$ (Psh) (Tables 1 and 2). After six days of culture Pth exhibited the highest growth rate $\left(0.9\right.$ division day $\left.{ }^{-1}\right)$, reaching a concentration of $20.9 \times 10^{6}$ cell ml$^{-1}$. The other species exhibited a similar growth

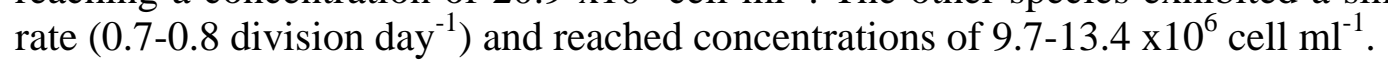

Protein content of the six strains ranged from 33.8-54.3\% of organic matter, and thus represented the main chemical component, except for Pth, where carbohydrates were dominant. Carbohydrates accounted for 30.2-44.2\% of organic matter, while lipids showed the most variability between species, ranging between 15.5\% (Pfl) and 29.2\% (Psh) of organic matter content.

Table 2. Dry weight, ash content and gross composition of the six pavlovophytes used in the present feeding trials (mean \pm S.D.; $\mathrm{n} \geq 2$ ).

\begin{tabular}{|c|c|c|c|c|c|c|}
\hline & Pfl & Psh & Psm & Ppi & Pth & Rsa \\
\hline $\begin{array}{l}\text { Dry weight } \\
\text { (pg cell }^{-1} \text { ) } \\
\text { Ash } \\
\text { (\% dry weight) } \\
\text { Proteins } \\
\text { (\% organic matter) } \\
\text { Carbohydrates } \\
\text { (\% o.m.) } \\
\text { Lipids } \\
\text { (\% o.m.) }\end{array}$ & $\begin{array}{l}14.8 \pm 0.4 \\
6.9 \pm 0.8 \\
54.3 \pm 2.5 \\
30.2 \pm 0.7 \\
15.5 \pm 1.8\end{array}$ & $\begin{array}{l}28.8 \pm 0.5 \\
13.5 \pm 0.8 \\
41.3 \pm 0.7 \\
29.5 \pm 1.1 \\
29.2 \pm 1.8\end{array}$ & $\begin{array}{l}20.5 \pm 1.4 \\
13.9 \pm 0.5 \\
40.2 \pm 6.6 \\
36.3 \pm 3.5 \\
23.5 \pm 3.1\end{array}$ & $\begin{array}{l}23.0 \pm 0.8 \\
5.2 \pm 0.2 \\
38.1 \pm 1.4 \\
38.2 \pm 1.2 \\
23.8 \pm 0.2\end{array}$ & $\begin{array}{l}20.2 \pm 0.4 \\
5.8 \pm 0.4 \\
33.8 \pm 4.8 \\
44.2 \pm 3.3 \\
22.0 \pm 1.5\end{array}$ & $\begin{array}{l}18.2 \pm 1.1 \\
5.0 \pm 0.2 \\
44.6 \pm 0.1 \\
32.3 \pm 0.3 \\
23.1 \pm 0.2\end{array}$ \\
\hline
\end{tabular}


The six microalgae exhibited differences in fatty acid contents, ranging from $6.4 \%$ (R. salina) to $16.3 \%$ (Pth) of organic matter (Table 3 ). In contrast, fatty acid composition was broadly similar among the different strains, with some exceptions. The main fatty acids found were the saturated 14:0, 16:0, the monounsaturated 16:1(n-7) and the polyunsaturated EPA; these fatty acids accounted for more than $60 \%$ of total content. The polyunsaturated fraction formed the main fatty acid component in all species (35-56\% of total), while the saturated and monounsaturated fractions accounted for $28-39 \%$ and $13-31 \%$ of total fatty acids, respectively. As concerns PUFA, all species were rich in EPA ( $\geq 15 \%$ of total), while DHA varied significantly among different strains; in particular Psh and Pfl exhibited high DHA content ( $\approx 9-10 \%$ of total fatty acids), while in Psm and in $P$. pinguis this fatty acid accounted for only $3-4 \%$. The PUFA contents of the six strains expressed as a percentage of total organic matter content are illustrated in Fig.1. The highest PUFA content was found in Pth, followed by Pfl, Psm, $P$. pinguis, $R$. salina and Psh, in that order.

Neutral sterols of the six strains represented $0.4-2.1 \%$ of organic matter content (Table 4 ). Among sterols, stigmasterol was found to be dominant in all species ( $\geq 53 \%$ of total), while both methylporiferasterol and $\beta$-sitosterol were well represented, with values of $8-15 \%$ and 5 $12 \%$, respectively. On the other hand, campesterol was found in small quantities (2-3\% of total) in all strains, while other sterols varied greatly among different strains. Pfl and Psh were particularly rich in 24-methylenecholesterol, Psm, $P$. pinguis and $R$. salina contained high quantities of ethylpavlovol, while Pth exhibited a significant content of $\beta$-sitosterol.

Fig. 1. PUFA content of the six pavlovophytes used in the present trials. Data are expressed as percentage of organic matter content $(n=2)$.

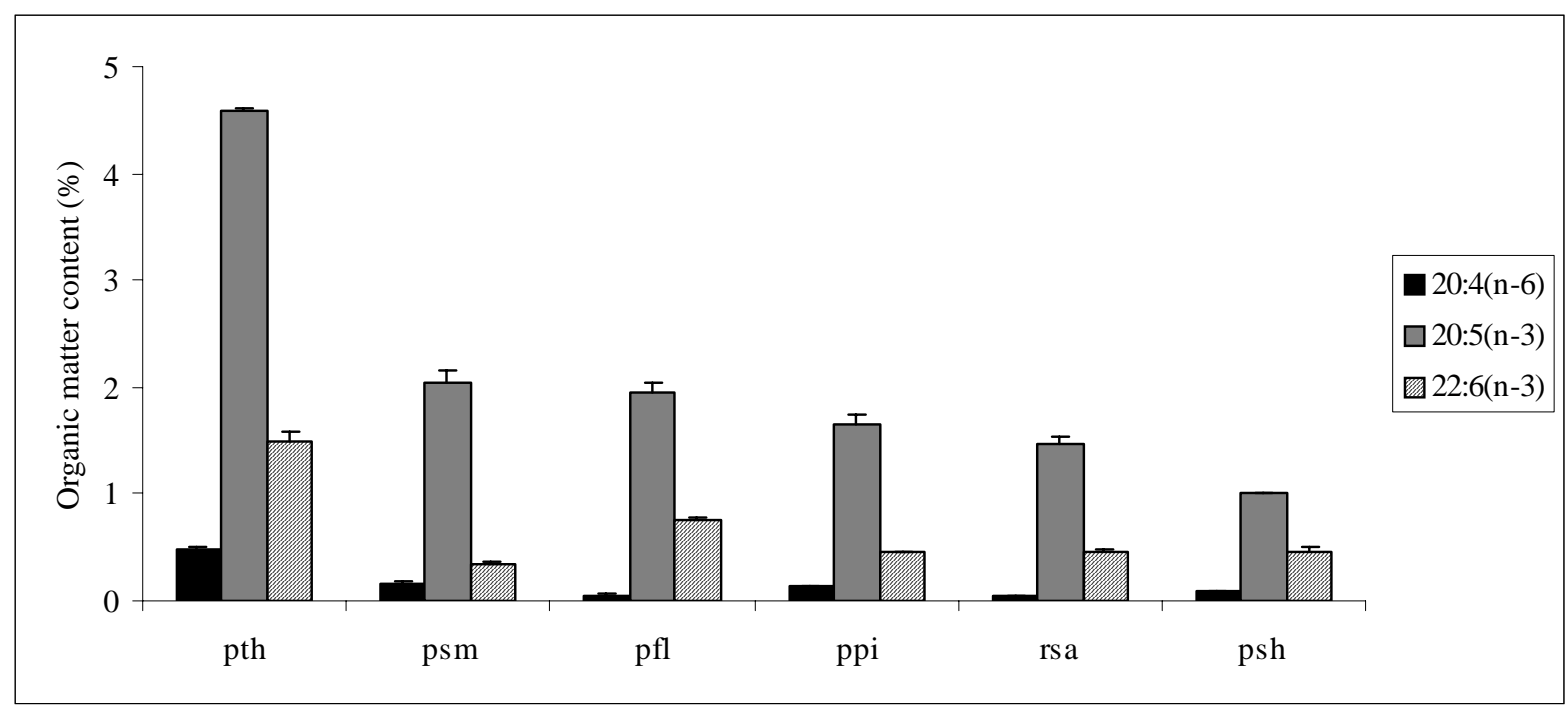


Fig. 2. Clearance of Crassostrea gigas larvae fed six different pavlovophytes over an $8 \mathrm{~h}$ period. $\mathrm{Pfl}=$ Pavlova sp. AC 250, Psh = Pavlova sp. AC248, Pth = Pavlova sp. AC 87, Psm = Pavlova sp. AC 538, Ppi = Pavlova pinguis and Rsa = Rebecca salina (ex Pavlova salina).

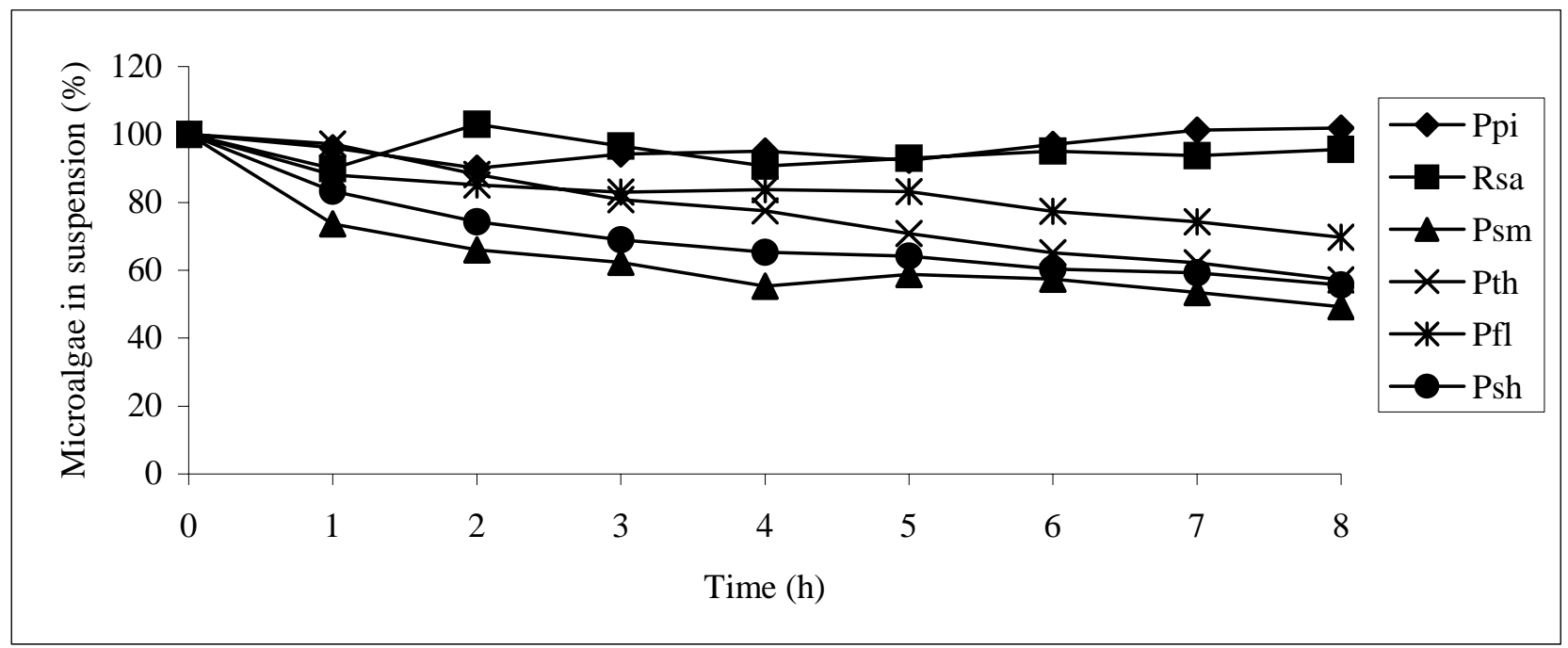

Both of the pavlovophyte strains tested during the first trial did not exhibit any nutritional value for $C$. gigas larvae (Table 5), similar to unfed larvae and by far lower then larvae fed Cp20 diet. The possibility that exudates from cultures of $P$. pinguis or $R$. salina were toxic was excluded by the second feeding trial results (Table 6). Both diets including the supernatant of these microalgae combined with $C$. calcitrans f. pumilum gave high survival and growth comparable to that obtained with the diatom only. In contrast, larvae fed with $R$. salina or $P$. pinguis cells centrifuged and resuspended in fresh medium exhibited poor growth during the first week and even higher mortality during the second week. The new species included in this trial (Psh) exhibited also a poor nutritional value for C. gigas larvae, with low growth compared to Cp20 diet and low survival after two weeks of rearing. 
Table 3. Fatty acid composition (mean $\pm \mathrm{SD} ; \mathrm{n}=2$ ) of the six pavlovophytes used in the present trials Individual data are reported as percentage of total fatty acids while total fatty acids (TO FA) are expressed either total dry weight or percentage of total organic matter content (o.m.).

\begin{tabular}{|c|c|c|c|c|c|c|}
\hline & Pfl & Psh & Psm & Ppi & Pth & Rsa \\
\hline $14: 0$ & $17.8 \pm 0.3$ & $10.7 \pm 0.2$ & $17.8 \pm 0.5$ & $15.9 \pm 0.6$ & $12.1 \pm 1.0$ & $20.0 \pm 0.6$ \\
\hline $16: 0$ & $12.9 \pm 0.8$ & $16.5 \pm 0.1$ & $14.5 \pm 1.2$ & $17.3 \pm 0.8$ & $26.5 \pm 0.9$ & $11.8 \pm 0.4$ \\
\hline $16: 1(n-7)$ & $9.0 \pm 0.5$ & $11.3 \pm 0.4$ & $28.2 \pm 0.9$ & $22.9 \pm 0.7$ & $15.2 \pm 0.4$ & $19.5 \pm 0.3$ \\
\hline $16: 2(n-4)$ & $1.4 \pm 0.3$ & $1.4 \pm 0.1$ & $1.5 \pm 0.2$ & $1.1 \pm 0.1$ & $0.9 \pm 0.1$ & $2.1 \pm 0.1$ \\
\hline $18: 2(n-6)$ & $1.1 \pm 0.2$ & $2.4 \pm 0.1$ & $1.8 \pm 0.2$ & $2.5 \pm 0.1$ & $3.6 \pm 0.1$ & $1.2 \pm 0.1$ \\
\hline $18: 3(n-3)$ & $1.3 \pm 0.2$ & $0.4 \pm 0.1$ & $0.3 \pm 0.1$ & $0.5 \pm 0.1$ & $0.3 \pm 0.1$ & $0.3 \pm 0.1$ \\
\hline $18: 4(n-3)$ & $10.1 \pm 0.7$ & $6.1 \pm 0.1$ & $4.0 \pm 0.7$ & $4.5 \pm 0.1$ & $3.6 \pm 0.1$ & $4.9 \pm 0.5$ \\
\hline $20: 4(n-6)$ & $0.6 \pm 0.1$ & $2.2 \pm 0.1$ & $1.3 \pm 0.1$ & $1.2 \pm 0.1$ & $2.1 \pm 0.1$ & $0.6 \pm 0.1$ \\
\hline $20: 5(n-3)$ & $22.6 \pm 1.2$ & $22.5 \pm 0.2$ & $15.4 \pm 1.0$ & $15.6 \pm 0.9$ & $19.6 \pm 0.1$ & $19.5 \pm 0.8$ \\
\hline $22: 5(n-6)$ & $8.3 \pm 0.4$ & $7.8 \pm 0.7$ & $5.3 \pm 0.1$ & $7.2 \pm 0.2$ & $4.9 \pm 0.1$ & $6.8 \pm 0.1$ \\
\hline $22: 6(n-3)$ & $8.8 \pm 0.3$ & $10.2 \pm 1.1$ & $2.6 \pm 0.1$ & $4.3 \pm 0.1$ & $6.4 \pm 0.4$ & $6.2 \pm 0.1$ \\
\hline TO.SAT. & $31.8 \pm 1.5$ & $27.6 \pm 0.4$ & $33.18 \pm 1.61$ & $33.9 \pm 2.1$ & $39.0 \pm 0.3$ & $32.8 \pm 1.3$ \\
\hline TO.MONO & $12.5 \pm 0.9$ & $16.7 \pm 0.8$ & $31.24 \pm 1.18$ & $26.1 \pm 1.2$ & $17.8 \pm 0.1$ & $22.1 \pm 0.1$ \\
\hline TO.(n-9) & $0.8 \pm 0.1$ & $0.9 \pm 0.1$ & $1.1 \pm 0.2$ & $1.9 \pm 0.2$ & $1.2 \pm 0.1$ & $1.3 \pm 0.1$ \\
\hline TO.(n-7) & $9.3 \pm 1.0$ & $11.5 \pm 0.4$ & $28.6 \pm 0.9$ & $23.3 \pm 1.0$ & $15.2 \pm 0.5$ & $19.8 \pm 0.3$ \\
\hline TO.POLY & $55.5 \pm 1.3$ & $55.7 \pm 1.2$ & $35.4 \pm 2.7$ & $40.1 \pm 1.7$ & $42.9 \pm 0.1$ & $45.0 \pm 1.2$ \\
\hline TO.(n-4) & $1.6 \pm 0.2$ & $1.5 \pm 0.1$ & $1.9 \pm 0.4$ & $1.2 \pm 0.1$ & $1.0 \pm 0.1$ & $2.3 \pm 0.1$ \\
\hline TO.(n-6) & $10.4 \pm 0.6$ & $14.6 \pm 0.2$ & $10.4 \pm 0.2$ & $13.2 \pm 0.8$ & $11.6 \pm 0.2$ & $11.0 \pm 0.2$ \\
\hline TO.(n-3) & $43.3 \pm 1.5$ & $39.6 \pm 1.1$ & $22.9 \pm 2.1$ & $25.6 \pm 1.4$ & $30.0 \pm 0.3$ & $31.5 \pm 1.4$ \\
\hline$(n-3) /(n-6)$ & $4.2 \pm 0.1$ & $2.7 \pm 0.4$ & $2.2 \pm 0.2$ & $1.9 \pm 0.1$ & $2.6 \pm 0.1$ & $2.9 \pm 0.2$ \\
\hline 22:6/20:5 & $0.4 \pm 0.1$ & $0.5 \pm 0.1$ & $0.2 \pm 0.1$ & $0.3 \pm 0.1$ & $0.3 \pm 0.1$ & $0.3 \pm 0.1$ \\
\hline $22: 5 / 20: 4$ & $13.6 \pm 0.3$ & $3.6 \pm 0.45$ & $4.00 \pm 0.2$ & $5.8 \pm 0.2$ & $2.3 \pm 0.3$ & $12.4 \pm 0.4$ \\
\hline $\mid \begin{array}{ll}\text { TO } & \text { FA } \\
\text { weight } & \text { (fg } \\
\text { cell }^{-1} \text { ) } & \end{array}$ & $1140.0 \pm 42.1$ & $1109.9 \pm 76.8$ & $2333.2 \pm 286.5$ & $2303.4 \pm 134.9$ & $4303.0 \pm 235.6$ & $1311.4 \pm 16.2$ \\
\hline $\begin{array}{l}\text { TO FA } \\
\text { o.m) }\end{array}$ & $7.7 \pm 0.6$ & $15.9 \pm 1.0$ & $10.7 \pm 2.3$ & $10.0 \pm 1.1$ & $16.3 \pm 0.9$ & $6.4 \pm 0.3$ \\
\hline
\end{tabular}

\subsection{Feeding trials}


Table 4. Sterol composition of the six pavlovophytes used in the present feeding trials (mean \pm SD; $n=2$ ). Individual data are reported as percentage of total sterols while total sterols (TO sterols) are expressed either total dry weight (fg cell ${ }^{-1}$ ) or percentage of total organic matter content $(\%$ o.m.).

\begin{tabular}{|l|c|l|l|l|l|l|}
\hline \hline & Pfl & Psh & Psm & Ppi & Pth & Rsa \\
\hline CHOL & $2.9 \pm 0.4$ & $5.4 \pm 0.3$ & & & $1.0 \pm 0.1$ & \\
BRA & & $0.5 \pm 0.1$ & & & $1.4 \pm 0.1$ & \\
DES & & $0.4 \pm 0.1$ & & & $2.0 \pm 0.1$ & \\
CAM & $2.3 \pm 0.4$ & $3.9 \pm 0.1$ & $2.8 \pm 0.1$ & $2.1 \pm 0.1$ & $2.6 \pm 0.1$ & $1.8 \pm 0.1$ \\
24-MET & $19.3 \pm 0.7$ & $12.5 \pm 0.1$ & & $5.9 \pm 0.5$ & & \\
STI & $53.1 \pm 0.3$ & $52.8 \pm 0.1$ & $59.2 \pm 0.2$ & $59.5 \pm 0.4$ & $60.1 \pm 0.2$ & $64.1 \pm 2.4$ \\
MeP & $15.1 \pm 0.5$ & $10.5 \pm 0.1$ & $10.9 \pm 0.1$ & $8.3 \pm 0.1$ & $16.4 \pm 0.3$ & $11.0 \pm 0.7$ \\
$\beta$-SI & $5.9 \pm 0.9$ & $11.6 \pm 0.1$ & $9.9 \pm 0.5$ & $10.2 \pm 0.4$ & $4.9 \pm 0.1$ & $7.8 \pm 0.3$ \\
FUC & & $1.1 \pm 0.1$ & $4.5 \pm 0.1$ & $3.8 \pm 0.2$ & $10.1 \pm 0.1$ & $4.2 \pm 0.3$ \\
ISOFUC & & $0.9 \pm 0.2$ & $0.5 \pm 0.1$ & $0.4 \pm 0.1$ & & \\
MET & $1.5 \pm 0.1$ & $0.5 \pm 0.1$ & $10.8 \pm 0.2$ & $8.5 \pm 0.1$ & $1.0 \pm 0.1$ & $9.6 \pm 1.3$ \\
ETH & $192.1 \pm 37.8$ & $444.3 \pm 0.1$ & $336.9 \pm 47.8$ & $352.8 \pm 26.8$ & $394.3 \pm 24.5$ & $298.0 \pm 3.0$ \\
TO sterol weight & & & & & & \\
(fg cell ${ }^{-1}$ ) & & & & & & \\
TO sterol & $1.5 \pm 0.3$ & $1.8 \pm 0.1$ & $1.9 \pm 0.3$ & $0.4 \pm 0.1$ & $2.1 \pm 0.1$ & $1.7 \pm 0.1$ \\
(\% 0.m.) & & &
\end{tabular}

CHOL = Cholesterol (Cholesta-5-en-3 $\beta$-ol);

BRA = Brassicasterol (24 $\beta$-methylcholesta-5,22-dien-3 $\beta$-ol);

DES = Desmosterol (cholesta-5-en-3 $\beta$-ol);

CAM = Campesterol (24 $\alpha$-methylcholesta-5-en-3 $\beta$-ol);

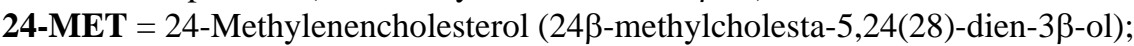

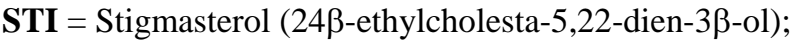

MEP $=4 \alpha$-Methylporiferastenol ( $4 \alpha$-methyl-24 $\alpha$-ethylcholesta-22-en-3 $\beta$-ol);

$\beta$-SI $=\beta$-Sitosterol (24 $\beta$-ethylcholesta-5-en-3 $\beta$-ol);

FUC = Fucosterol (24 $\beta$-ethylcholesta-5,24(28)-dien-3 $\beta$-ol);

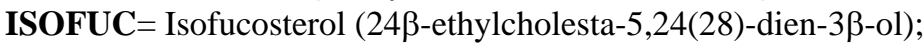

MET = methylpavlovol ( $4 \alpha, 24 \beta$-dimethylcholestan-3 $\beta, 4 \beta$-diol $)$;

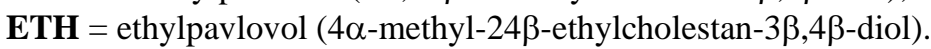


Table 5 Length and survival (average \pm S.D.) of C. gigas larvae fed different diets. Initial shell length $=83.0 \pm$ $5.5 \mu \mathrm{m}$. Values within the same column sharing a common superscript letter are not significantly different $(P>0.05)$. Cp+Ti: $C$. calcitrans f. pumilum + T-Iso; Cp+Rsa: $C$. calcitrans f. pumilum + R. salina; Cp+Ppi: $C$. calcitrans f. pumilum + P. pinguis; Cp100 C. calcitrans f. pumilum (100\% of ration); Cp20 C. calcitrans $\mathrm{f}$. pumilum (20\% of ration); Unfed: starved larvae.

\begin{tabular}{|l|ll|ll|}
\hline \hline & $\begin{array}{l}\text { First week } \\
\text { length }\end{array}$ & survival & $\begin{array}{l}\text { Second week } \\
\text { length }\end{array}$ & survival \\
\hline \hline cp+Ti & $125.8 \pm 20.1^{\mathrm{a}}$ & $91.1 \pm 0.9^{\mathrm{b}}$ & $175.1 \pm 42.1$ & $89.7 \pm 0.5^{\mathrm{a}}$ \\
$\mathbf{\text { p}}+\mathbf{R s a}$ & $87.3 \pm 5.3^{\mathrm{b}}$ & $84.0 \pm 7.4^{\mathrm{c}}$ & $89.0 \pm 5.2^{\mathrm{a}}$ & $20.1 \pm 2.8$ \\
$\mathbf{\text { Cp+Ppi }}$ & $85.1 \pm 4.9^{\mathrm{b}}$ & $81.7 \pm 5.0^{\mathrm{c}}$ & $87.1 \pm 3.9^{\mathrm{a}}$ & $8.3 \pm 1.6$ \\
$\mathbf{c p 1 0 0}$ & $129.3 \pm 19.5^{\mathrm{a}}$ & $94.2 \pm 1.2^{\mathrm{ab}}$ & $149.5 \pm 29.8$ & $89.1 \pm 0.6^{\mathrm{ab}}$ \\
$\mathbf{C p 2 0}$ & $110.9 \pm 12.3$ & $93.2 \pm 1.9^{\mathrm{ab}}$ & $121.3 \pm 15.0$ & $83.1 \pm 1.4^{\mathrm{b}}$ \\
Unfed & $91.6 \pm 6.8$ & $95.7 \pm 1.3^{\mathrm{a}}$ & $92.1 \pm 6.7^{\mathrm{a}}$ & $84.3 \pm 3.0^{\mathrm{ab}}$ \\
\hline \hline
\end{tabular}

Table 6 Length and survival (average \pm S.D.) of $C$. gigas larvae fed different diets. Initial shell length $=81.1 \pm$ $4.4 \mu \mathrm{m}$. Values within the same column sharing a common superscript letter are not significantly different $(P>0.05)$. Cp+Ti: C. calcitrans f. pumilum + T-Iso; Cp+Pps: C. calcitrans f. pumilum + P. pinguis surnatant; Cp+Rss: C. calcitrans f. pumilum $+R$. salina surnatant; $\mathbf{C p + P p c : ~ C . ~ c a l c i t r a n s ~ f . ~ p u m i l u m ~}+P$. pinguis resuspended; Cp+Rss: C. calcitrans f. pumilum + R. salina resuspended;Cp20 C. calcitrans f. pumilum (20\% of ration); Cp+Pps: C. calcitrans f. pumilum + Pavlova sp. AC248; Unfed: starved larvae.

\begin{tabular}{|l|ll|ll|}
\hline \hline & $\begin{array}{l}\text { First week } \\
\text { length }\end{array}$ & survival & $\begin{array}{l}\text { Second week } \\
\text { Length }\end{array}$ & survival \\
\hline \hline Cp+Ti & $127.0 \pm 14.0$ & $98.5 \pm 0.3^{\mathrm{ab}}$ & $160.7 \pm 14.0$ & $95.9 \pm 1.2^{\mathrm{a}}$ \\
$\mathbf{C p}+\mathbf{P p s}$ & $115.7 \pm 11.3^{\mathrm{ab}}$ & $98.8 \pm 0.4^{\mathrm{ab}}$ & $137.7 \pm 17.0^{\mathrm{a}}$ & $95.4 \pm 2.1^{\mathrm{a}}$ \\
$\mathbf{C p + R s s}$ & $117.6 \pm 11.3^{\mathrm{a}}$ & $98.9 \pm 0.8^{\mathrm{ab}}$ & $139.5 \pm 15.0^{\mathrm{a}}$ & $96.8 \pm 1.5^{\mathrm{a}}$ \\
$\mathbf{P p c}$ & $83.0 \pm 3.9^{\mathrm{c}}$ & $92.2 \pm 5.9^{\mathrm{b}}$ & n.d. & $6.8 \pm 2.0^{\mathrm{b}}$ \\
Rsc & $83.0 \pm 4.8^{\mathrm{c}}$ & $92.9 \pm 4.7^{\mathrm{b}}$ & n.d. & $7.4 \pm 2.1^{\mathrm{b}}$ \\
$\mathbf{C p 2 0}$ & $115.0 \pm 11.2^{\mathrm{b}}$ & $96.3 \pm 1.3^{\mathrm{ab}}$ & $135.9 \pm 14.6^{\mathrm{a}}$ & $96.3 \pm 1.0^{\mathrm{a}}$ \\
Cp+Psh & $98.7 \pm 9.0$ & $99.3 \pm 0.4^{\mathrm{ab}}$ & $102.6 \pm 10.4$ & $23.3 \pm 11.7$ \\
Unfed & $87.4 \pm 4.0$ & $99.5 \pm 0.5^{\mathrm{a}}$ & $88.2 \pm 4.3^{\mathrm{d}}$ & $90.2 \pm 5.9^{\mathrm{a}}$ \\
\hline \hline
\end{tabular}

After two weeks of rearing among the three species tested in the third feeding trial (Table 7) only Pfl gave growth and survival similar to the reference diet Cp only, while the others resulted in lower larval performances.

Grazing by C. gigas larvae varied for the six strains (Fig. 1). In particular, $P$. pinguis and $R$. salina were weakly ingested and more than $95 \%$ of cells still remained in suspension eight hours after delivery. In contrast, the four other strains were more efficiently ingested (30-50\% of cells ingested eight hours latter). 
Table 7 Length and survival (average \pm S.D.) of C. gigas larvae fed different diets. Initial shell length $=78.2 \pm$ $4.8 \mu \mathrm{m}$. Values within the same column sharing a common superscript letter are not significantly different $(P>0.05)$. Cp+Ti: C. calcitrans f. pumilum + T-Iso; Cp+Pfl: C. calcitrans f. pumilum + Pavlova sp. AC 250; Cp+Pth: C. calcitrans f. pumilum + Pavlova sp. AC 251; Cp+Psm: C. calcitrans f. pumilum + Pavlova sp. AC;Cp100 C. calcitrans f. pumilum (100\% of ration); Cp20 C. calcitrans f. pumilum (20\% of ration); Unfed: starved larvae.

\begin{tabular}{|l|ll|ll|}
\hline \hline & $\begin{array}{l}\text { First week } \\
\text { length }\end{array}$ & survival & $\begin{array}{l}\text { Second week } \\
\text { length }\end{array}$ & survival \\
\hline \hline cp+Ti & $112.3 \pm 23.15^{\mathrm{a}}$ & $79.4 \pm 4.7^{\mathrm{b}}$ & $192.8 \pm 41.8$ & $62.9 \pm 4.5^{\mathrm{ab}}$ \\
$\mathbf{\text { cp+Pfl }}$ & $100.2 \pm 16.41$ & $86.2 \pm 2.5^{\mathrm{ab}}$ & $140.5 \pm 36.7^{\mathrm{a}}$ & $57.9 \pm 11.8^{\mathrm{ab}}$ \\
$\mathbf{\text { cp+Pth }}$ & $92.0 \pm 10.1^{\mathrm{b}}$ & $90.6 \pm 4.9^{\mathrm{ab}}$ & $117.7 \pm 24.5$ & $57.7 \pm 11.0^{\mathrm{ab}}$ \\
$\mathbf{\text { cp+PSm }}$ & $88.0 \pm 9.7^{\mathrm{b}}$ & $90.2 \pm 2.8^{\mathrm{ab}}$ & $103.3 \pm 24.2$ & $42.0 \pm 6.3^{\mathrm{b}}$ \\
$\mathbf{\text { cp100 }}$ & $117.1 \pm 26.2^{\mathrm{a}}$ & $87.3 \pm 6.4^{\mathrm{ab}}$ & $159.7 \pm 35.7$ & $64.4 \pm 6.2^{\mathrm{ab}}$ \\
$\mathbf{\text { cp20 }}$ & $113.1 \pm 20.2^{\mathrm{a}}$ & $92.5 \pm 2.6^{\mathrm{ab}}$ & $143.5 \pm 23.1^{\mathrm{a}}$ & $71.2 \pm 1.1^{\mathrm{a}}$ \\
Unfed & $81.4 \pm 4.6$ & $95.4 \pm 3.4^{\mathrm{a}}$ & $83.9 \pm 4.0$ & $58.0 \pm 2.6^{\mathrm{ab}}$ \\
\hline \hline
\end{tabular}

After one week of $P$. maximus larvae rearing, the low food value of $R$. salina, $P$. pinguis, Psm and Pth was confirmed, resulting in growth similar to unfed larvae (Table 8). Larvae fed $\mathrm{Cp}+\mathrm{Psh}$ diet exhibited similar growth to positive control $(\mathrm{Cp}+\mathrm{Ti})$, while larvae fed $\mathrm{Cp}+\mathrm{Pfl}$ showed better growth rates. During the second week, the best larval performances on $\mathrm{Cp}+\mathrm{Pfl}$ diet were confirmed. No significant differences were found among the control diet $\mathrm{Cp}+\mathrm{Ti}$ and $\mathrm{Cp}+\mathrm{Psh}, \mathrm{Cp}+\mathrm{Pth}$ and $\mathrm{Cp}+\mathrm{Rsa}$, while larvae fed $\mathrm{P}$. pinguis or Psm exhibited development similar to unfed larvae. However, these latter strains exhibited unusual growth during the trial, possibly due to the occurrence of an unusual picoplancton bloom in the hatchery reservoir. The use of antibiotics during the trial resulted in high survival $(\geq 91 \%)$ in all cases.

Table 8 Length and survival (average \pm S.D.) of $P$. maximus larvae fed different diets. Initial shell length= $93.7 \pm$ $10.2 \mu \mathrm{m}$. Values within the same column sharing a common superscript letter are not significantly different $(P>0.05)$.

\begin{tabular}{|c|c|c|c|c|}
\hline & $\begin{array}{l}\text { First week } \\
\text { length }\end{array}$ & survival & $\begin{array}{l}\text { Second week } \\
\text { length }\end{array}$ & survival \\
\hline $\bar{C} \mathbf{C p + T i}$ & $133.7 \pm 20.1^{\mathrm{a}}$ & $96.1 \pm 1.3^{\mathrm{a}}$ & $164.0 \pm 34.4^{\mathrm{a}}$ & $888.6 \pm 1.1^{\mathrm{a}}$ \\
\hline cp+Pfl & $142.8 \pm 29.8$ & $98.0 \pm 2.1^{\mathrm{a}}$ & $208.0 \pm 38.4$ & $95.1 \pm 0.5^{\mathrm{a}}$ \\
\hline ср+Ppi & $122.5 \pm 16.6^{\mathrm{b}}$ & $96.7 \pm 0.8^{\mathrm{a}}$ & $140.4 \pm 26.4^{\mathrm{c}}$ & $92.3 \pm 1.4^{\mathrm{a}}$ \\
\hline cp+Psh & $134.6 \pm 20.4^{\mathrm{a}}$ & $97.7 \pm 0.6^{\mathrm{a}}$ & $164.0 \pm 37.5^{\mathrm{a}}$ & $93.4 \pm 2.7^{\mathrm{a}}$ \\
\hline сp+Psm & $122.1 \pm 16.2^{\mathrm{b}}$ & $96.9 \pm 0.3^{\mathrm{a}}$ & $146.9 \pm 21.0^{\mathrm{bc}}$ & $92.2 \pm 3.8^{\mathrm{a}}$ \\
\hline cp+Pth & $124.4 \pm 17.0^{\mathrm{b}}$ & $96.6 \pm 0.6^{\mathrm{a}}$ & $158.1 \pm 31.3^{\mathrm{ab}}$ & $93.1 \pm 2.2^{\mathrm{a}}$ \\
\hline cp+Rsa & $121.0 \pm 18.5^{\mathrm{b}}$ & $98.5 \pm 0.5^{\mathrm{a}}$ & $152.8 \pm 24.1^{\mathrm{ab}}$ & $91.9 \pm 0.5^{\mathrm{a}}$ \\
\hline Unfed & $120.5 \pm 15.7^{\mathrm{b}}$ & $96.6 \pm 0.6^{\mathrm{a}}$ & $139.5 \pm 23.5^{\mathrm{c}}$ & $90.6 \pm 1.2^{\mathrm{a}}$ \\
\hline
\end{tabular}




\section{Discussion}

At present, a certain level of mastery of the main procedures employed in mollusc hatcheries has been reached (Helm and Bourne, 2004), but nevertheless several constraints remain unsolved. In particular, larval rearing is strictly dependent on phytoplankton production, an activity that requires considerable human and economic investment. The number of microalgal strains routinely used in hatcheries is extremely limited, particularly as concerns flagellates, and the search for suitable new strains is clearly a priority. The effectiveness of microalgae as food for mollusc larvae depends on several criteria such as size, shape, availability in the water column, digestibility, biochemical profile and culture productivity (Webb and Chu, 1983; Brown et al., 1989, Robert et al., 2004). The haptophyte class Pavlovophyceae includes species that potentially fulfil these criteria.

The nutritional value for molluscs of the pavlovophytes $P$. lutheri, $P$. pinguis and $R$. salina has been widely investigated (Walne, 1970; Langdon and Waldock, 1981; Brown et al., 1998; Jonsson et al., 1999; McCausland et al., 1999; Heasman et al., 2000; Ponis et al., 2003a,b), and more recently another pavlovophyte, Diacronema vlkianum, has been shown to be of interest for C. gigas larvae (Ponis et al., 2005). In the present study, various characteristics (size, cell density, productivity, biochemical composition) of six pavlovophytes have been assessed and their food value for $C$. gigas and $P$. maximus larvae examined.

All strains included in this study were of appropriate size $(3.8-5.3 \mu \mathrm{m})$ to be ingested by $C$. gigas larvae and exhibited high productivities, reaching at least a concentration of $10 \times 10^{6}$ cells $\mathrm{ml}^{-1}$ after six days of culture in 2-l carboys. Similar values have been reported for the flagellate strain T-Iso, which is routinely cultured in mollusc hatcheries and considered as a reference strain.

All of the tested microalgae exhibited high protein and carbohydrate contents (34-54\% and $30-44 \%$ of organic matter, respectively). These levels are similar to those reported in the literature for bivalve requirements. For example, Brown et al. (1989) stated that microalgal protein content should account for 30-60\% of dry weight, while Utting (1986) noted that high carbohydrate contents are required for acceptable larval $C$. gigas development. The gross composition of $P$. pinguis measured here was coherent with the values recorded for the same species by McCausland et al. (1999), while $R$. salina lipid content was similar to that analysed by Volkman et al. (1991). The six pavlovophytes studied here showed similar fatty acid profiles. All species were rich in 14:0, 16:0 and EPA (48-58\% of total fatty acids), while DHA content varied significantly among species; these fatty acids are fundamental for oyster normal larval and post-larval developments (Langdon and Waldock, 1981, Thompson et al., 1993). The fatty acid composition of $P$. pinguis measured in this study was similar to that reported by Volkman et al. (1997), while higher saturated and monounsaturated contents and lower polyunsaturated fatty acid levels (with particular reference to EPA and DHA) were reported for the same species by McCausland et al. (1999). Apart from a lower content of 16:1(n-7) and higher concentrations of 18:4(n-3) EPA and DHA reported here, the fatty acid profile of $R$. salina corresponds to that reported for the same species by Volkman et al. (1991). Ethylpavlovol was detected in all six pavlovphytes, while methylpavlovol was found in only four strains (Psm, P. pinguis, Pth, R. salina). These sterols, specific to members of the order Pavlovales, are however poorly incorporated by C. gigas spat or Pecten maximus larvae (Soudant et al., 1998; Knauer et al., 1999) and this fact might partially explain their low nutritional value. The sterol profile of $P$. pinguis measured in our study was similar to that 
described by Volkman et al. (1997), but different from that reported by Ghosh et al. (1998) for the same species.

In spite of balanced biochemical profiles, bispecific diets including the different pavlovophytes were of poor food value for $C$. gigas and in fact, except for the diet including $\mathrm{Pfl}$, the nutritional value of the associated diatom was depressed (i.e. lower larval performances than that obtained with the control Cp20 only). $P$. pinguis and $R$. salina were poorly ingested, as shown in eight hour larval feeding trials. No negative effects of exudates of cultures were detected, and thus the low ingestion rate was apparently not due to exo-toxin production. Similar observations on $C$. gigas larvae were reported for $P$. lutheri: no negative effects of exudates (Ponis et al., 2003b) but low cells consumption (Robert et al., 2005). During feeding trials with Pecten maximus larvae, $P$. pinguis and Psh led to poor larval development, similar to that of unfed larvae. After two weeks of rearing, unfed larvae exhibited a significant increase in shell length. An abnormal picoplancton bloom was detected in the hatchery reservoir and despite fine water filtration (sequential cartridge filtration at 5 and $1 \mu \mathrm{m})$ an increase of organic particulates and/or natural phytoplankton in filtered seawater was suspected. Pecten maximus larvae fed with Pfl exhibited relatively high survival and significantly greater growth after two weeks of rearing than that measured with the reference diet $\mathrm{Cp}+\mathrm{Ti}$.

Although several studies on the nutritional value of microalgae and basic nutritional requirements of reared molluscs have been carried out, their relationships remain poorly defined. The food value of a given microalga depends on both the mollusc species and growth stage considered (Brown et al., 1997; Knauer and Southgate, 1999; Muller-Feuga et al., 2003). For example, in the present study the low food value of $R$. salina for $C$. gigas and $P$. maximus larvae has been demonstrated. However, this species has been reported to be of interest when used as food for Pecten margaritifera larvae and for C. gigas juveniles (Brown et al., 1998; Doroudi et al., 2003).

This study clearly indicates that cultures of members of the class Pavlovophyceae are unsuitable for larval C. gigas feeding, leading to poor growth and low survival. In contrast, promising results for $P$. maximus larval rearing were obtained with a new pavlovophyte strain. Further investigations on its productivity in commercial operating conditions should be performed in order to promote its use in hatcheries.

\section{Acknowledgments}

This study was partially supported by the Groupe Régional d'Action pour la Valorisation Industrielle de la Recherche Basse-Normandie, France, through a postdoctoral grant. The authors are indebted to JP Connan for providing assistance in culturing microalgae and to the hatchery of Tinduff for providing scallop larvae. 


\section{References}

Bligh, W.J., Dyer, W.J., 1959. A rapid method of total lipid extraction and purification. Can. J. Biochem. Physiol. 37, 911-917.

Brown, M.R., Jeffrey, S.W., Garland, C.D., 1989. Nutritional Aspects of Microalgae used in Mariculture; a Literature Review. CSIRO Marine Laboratories Report, 205, pp. 43.

Brown, M.R., Volkman, J.K., Dunstan, G.A., 1997. Nutritional properties of microalgae for mariculture. Aquaculture 151, 315-331.

Brown, M.R., McCausland, M., Kowalski, K., 1998. The nutritional value of four Australian microalgal strains fed to Pacific oyster Crassostrea gigas spat. Aquaculture 165, 281-293.

Coutteau, P., Sorgeloos, P., 1992. The use of algal substitutes and the requirement for live algae in hatchery and nursery rearing of bivalve molluscs: an international survey. J. Shell. Res. 11, 467-476.

Doroudi, M.S., Southgate, P.C., Mayer, R.J., 1999. Growth and survival of black-lip pearl oyster fed different densities of microalgae. Aquacult. Int. 7, 179-187.

Doroudi, M.S., Southgate, P.C., Lucas, J.S., 2003. Variation in clearance and ingestion rates by larvae of the black-lip pearl oyster (Pinctada margaritifera, L) feeding on various microalgae. Aquacult. Nutr. 9, 11-16.

Dubois, M., Gilles, K.A., Hamilton, J.K., Rebers, P.A., Smith, F., 1956. Colorimetric method for determination of sugars and related substances. Anal. Chem. 28, 350-356.

Ghosh, P., Patterson, G.W., Wikfors, G.H., 1998. Sterols of some Prymnesiophyceae. J. Phycol. 34, 511-514.

Heasman, M.P., Diemar, J., O' Connor, W., Sushames, T., Foulkes, L., 2000. Development of extended shelf-life microalgae concentrate diets harvested by centrifugation for bivalve molluscs - a summary. Aquac. Res. 31, 637-659.

Helm, M.M., Bourne, N., 2004. Hatchery culture of bivalves. A practical manual. FAO Fisheries Technical Paper 471, pp. 176.

Jonsson, P.R., Berntsson, K.M., André, C., Wängberg, S. A., 1999. Larval growth and settlement of the European oyster (Ostrea edulis) as a function of food quality measured as fatty acid composition. Mar. Biol. 134, 559-570.

Kanazawa, A., Teshima, S., Ono, K., 1979. Relationships between the essential fatty acid requirement of aquatic animals and their capacity for bioconversion of linoleic acid to highly unsaturated fatty acid. Comp. Biochem. Physiol. 63B, 295-298.

Knauer, J., Barrett, S.M., Volkman, J.K., Southgate, P.C., 1999. Assimilation of dietary phytosterols by Pacific oyster Crassostrea gigas spat. Aquacult. Nutr. 5, 257-266.

Knauer, J., Southgate, P.C., 1999. A review of the nutritional requirements of bivalves and the development of alternative and artificial diets for bivalve aquaculture. Rev. Fish. Sci. 7, 241-280.

Knuckey, R.M., Brown, M.R., Barrett, S.M., Hallegraeff, G.M., 2002, Isolation of new nanoplanktonic diatom strains and their evaluation as diets for juvenile Pacific oyster (Crassostrea gigas). Aquaculture 211, 253-274.

Langdon, C.J., Waldock, J., 1981. The effect of algal and artificial diets on the growth and fatty acid composition of Crassostrea gigas spat. J. Mar. Biol. Ass. U.K. 61, 431-448.

Laing, I., 2004. Filtration of king scallops (Pecten maximus). Aquaculture 240, 369-384.

Lowry, O.H., Rosebrough, N.J., Farr, A.L., Randall, R.J., 1951. Protein measurement with the folin phenol reagent. J. Biol. Chem. 193, 265-275.

Marty, Y., Delaunay, F., Moal, J., Samain, J.F., 1992. Changes in the fatty acid composition of Pecten maximus (L.) during larval development. J. Exp. Mar. Biol. Ecol. 163 (2), 221234.

McCausland, M. A., Brown, M.R., Barrett, S.M., Diemar, J.A., Heasman, M.P., 1999. 
Evaluation of live microalgal pastes as supplementary food for juvenile Pacific oyster (Crassostrea gigas). Aquaculture 174, 323-342.

Muller-Feuga, A, Moal, J., Kaas, R., 2003. The microalgae of Aquaculture. In: Støttrup, J.G., McEvoy, L.A. (Eds), Live Feeds in Marine Aquaculture. Blackwell, Oxford, 206-252.

Ponis, E., Robert, R., Parisi, G., 2003a. Nutritional value of fresh and concentrated algal diets for larval and juvenile Pacific oyster (Crassostrea gigas). Aquaculture 221, 491-505.

Ponis, E., Robert, R., Parisi, G., Tredici, M., 2003b. Assessment of the performance of Pacific oyster (Crassostrea gigas) larvae fed with fresh and preserved Pavlova lutheri concentrates. Aquacult. Int. 11, 69-79.

Ponis, E., Probert, I., Véron, B., Connan, J.P., Mathieu., M., Robert, R., 2005. New microalgae for mollusc hatchery. International Conference "LARVI '05”, Ghent, Belgium, 05-09 September 2005, Book of Abstract, 408-411.

Renaud, S.M., Luong-Van, T., Parry, D.L., 1999. The gross chemical composition and fatty acid composition of 18 species of tropical Australian microlagae for possible use in mariculture. Aquaculture 170, 147-159.

Renaud, S.M., Thinh, L.-V., Lambrinidis, G., Parry, D.L., 2002. Effect of temperature on growth, chemical composition and fatty acid composition of tropical Australian microalgae grown in batch cultures. Aquaculture 211, 195-214.

Robert, R., Parisi, G., Rodolfi, L, Poli, B.M., Tredici, M.R., 2001. Use of fresh and preserved Tetraselmis suecica for feeding Crassostrea gigas larvae. Aquaculture, 192 : 333-346.

Robert, R., Chretiennot-Dinet, M.J., Kaas, R., Martin-Jezequel, V., Moal, J., Le Coz, J.R., Nicolas, J.L., Bernard, E., Connan, J.P., Le Dean, L., Le Gourrierec, G., Leroy, B., Quéré, C., 2004. Amélioration des production phytoplanctoniques en écloserie de mollusques: caractérisation des microalgues fourrage. Report Ifremer DRV/RA/RST/LPI/2004-05, pp.150.

Robert, R., Rico-Villa, B., Mingant, C., sous presse. Influence of sole and plurispecific diets on larval consumption and development of Pacific oyster Crassostrea gigas (Thunberg). Oyster Reseach Institute News.

Soudant, P., Marty, Y., Moal, J., Samain, J.F., 1995. Separation of major polar lipids in Pecten maximus by high-performance liquid chromatography and subsequent determination of their fatty acids using gas chromatography. J. Chromatogr. 63B, 15-26.

Soudant, P., Le Coz, J.R., Marty, Y., Moal, J., Robert, R., 1998. Incorporation of Microalgae Sterols by Scallop Pecten maximus (L.) larvae. Comp. Biochem. Physiol. 119A(2), 451457.

Soudant, P., Van Sanles, M., Quéré, C., Le Coz, J. R., Marty, Y., Moal, J., Samain, J.F., Sorgeloos, P., 2000. The use of lipid emulsion for sterol supplementation of the Pacific oyster Crassostrea gigas. Aquaculture 184, 315-326.

Southgate, P.C., Beer, A.C., Duncan, P.F., Tamburri, R., 1998. Assessment of the nutritional value of three species of tropical microalgae, dried Tetraselmis and a yeast-based diet for the larvae of the blacklip pearl oyster, Pinctada margaritifera (L.). Aquaculture 162, 247257.

Southgate, P.C., Lee, P.S., 1998. Hatchery rearing of the tropical blacklip oyster Saccostrea echinata. Aquaculture 169, 275-281.

Thompson, P.A., Guo, M., Harrison, P.J., 1993. The influence of irradiance on the biochemical composition of three phytoplankton species and their nutritional value for larvae of the Pacific oyster (Crassostrea gigas). Mar. Biol. 117(2), 259-268.

Utting, S., 1986. A preliminary study on growth of Crassostrea gigas larvae and spat in relation to dietary protein. Aquaculture 56, 123-138.

Volkman, J.K., Dunstan, G.A., Jeffrey, S.W., Kearney, P.S., 1991. Fatty acids from microalgae of the genus Pavlova . Phytochemistry 30, 1855-1859. 
Volkman, J.K., Farmer, C.L., Barrett, S.M., Sikes, E.L., 1997. Unusual dihydroxysterols as chemotaxonomic markers for microalgae from the order Pavlovales (Haptophyceae). J. Phycol. 33, 1016-1023

Walne, P.R., 1966. Large scale culture of larvae Ostrea edulis L. Fish Invest. II 25 (4), 1-52.

Walne, P.R., 1970. Studies on the food value of ninteen genera of algae to juvenile bivalves of the genera Ostrea, Crassostrea, Mercenaria and Mytilus. Ministry of Agriculture Fisheries and Food (U.K.), Fisheries Investigation, 26, pp. 62.

Webb, K.L., Chu, F.L.E., 1983. Phytoplankton as a food source for bivalve larvae. Proceedings of the second international conference on aquaculture nutrition: biochemical and physiological approaches to shellfish nutrition. World Mariculture Society Sp. Publ. No. 2. Louisiana State University, 272-291. 